\title{
Fluorine F 18 SKI-249380
}

National Cancer Institute

\section{Source}

National Cancer Institute. Fluorine F18 SKI-249380. NCI Thesaurus. Code C111576.

A radioconjug ate composed of a derivative of the multi-targeted kinase inhibitor dasatinib conjug ated to the radioisotope fluorine $F 18$, with potential imaging activity during positron emission tomography (PET). Upon administration of fluorine F 18 SKI249380, the SKI-249380 moiety targets and binds to Bcr/Abl, SRC-family protein-tyrosine kinases, c-Kit and platelet-derived growth factor receptor (PDGFR). Upon binding, the fluorine F 18 moiety allows PET imaging of tumor cells and can be used as a tracer for the biodistribution of dasatinib. 